\title{
Strategy of Cluster Innovation in the Economic Transformation of Resource Cities of China: Experiences of Britain and Germany
}

\author{
Tao Meng ${ }^{1, *}$, Andrew M. Forman ${ }^{2}$ \\ ${ }^{1}$ Surrey International Institute, Dongbei University of Finance and Economics, Dalian, P.R. China \\ ${ }^{2}$ Frank G. Zarb School of Business, Hofstra University, New York, US
}

Email address:

mengtao@dufe.edu.cn (Tao Meng), andrew.m.forman@hofstra.edu (A. M. Forman)

*Corresponding author

\section{To cite this article:}

Tao Meng, Andrew M. Forman. Strategy of Cluster Innovation in the Economic Transformation of Resource Cities of China: Experiences of Britain and Germany. International Journal of Business and Economics Research. Vol. 5, No. 5, 2016, pp. 176-182.

doi: $10.11648 /$ j.ijber.20160505.16

Received: August 31, 2016; Accepted: September 18, 2016; Published: October 26, 2016

\begin{abstract}
The economic transformation of resource cities is one universal economic difficulty. The resource cities in China are confronted with double difficulties at the same time-resource exhaustion and economic system transformation. The economic transformation and social stableness of such cities are the important issues in the development and reformation of China. Industrial clusters are the network organizations of cooperative innovation and the effective polices to improve the regional development. It is very necessary for Chinese cities to improve the innovation and cooperation among organizations by industrial clusters and formulate industrial policies in relevant industries to promote the improvement of regional innovation capability and economic transformation. The resource cities will be transformed from old industrial regions based on the natural resources and capital into innovative industrial cluster based on the regional innovation capability and competence edge of the industry. This paper analyzes the conception of cluster innovation and introduces some experiences of Britain and Germany, then researches how the Chinese resource cities apply the strategy of cluster innovation to strengthen the regional innovation capability.
\end{abstract}

Keywords: Cluster Innovation, Economic Transformation, Industrial Cluster, Resource Cities

\section{Introduction}

With the exhaustion of resources, environmental degradation and other problems that become more and more severe, the resource cities in China have to face the challenge of economic depression, high unemployment and social unstableness resulting in highly weak regional innovation capability and gloomy urban development which need economic transformation urgently. The economic transformation of Chinese resource cities has become an emergent issue to be resolved for China's current economic development and social stableness [26]. State Council of China identified three groups of 69 resource exhausted cities and provides the support of public finance for the economic transformation of these cities from 2008 to 2011. In 2013, the central government also made the planning for sustainable development of total 262 resource cities which account for 39 percentages of all of cities in China. After development for many years, Chinese resource cities has formed a kind of industrial agglomeration where mining industry is primary and complemented by metallurgy, machinery manufacturing and other related industries, meanwhile a number of state-owned resource enterprises are centralized in the agglomerated area. However it is only a kind of regional production complex dominated by large enterprises, which is lack of enough number of small and middle sizes of enterprises (SMEs), vitality and interaction among enterprises. So they are not the real industrial cluster. This is the reason resulting in the low innovation capability of resource cities.

Whether the traditional industrial cluster in the northwest of Italy and high-tech industrial cluster in Silicon Valley of America or the cluster development in Zhejiang and 
Guangdong provinces in China, all of these regions have fully proven that industrial cluster is the form of industrial organizations and industrial policy to improve the regional economies and innovation capability. However, can the strategy of developing industrial cluster to promote regional innovation apply to the resource cities? And how the resource cities put the strategy of cluster innovation into practice? This paper is an exploratory research on these issues.

\section{Literature Review}

The question that innovation should be dominated by large enterprises or small enterprises has been a contentious topic in the research of innovation since Joseph Schumpeter created the innovation theory. In the age of network economy, the individual enterprises are impossible to shoulder a greater risk of innovation or achieve a valuable innovation activity, so innovation is gradually evolved into the result of cooperation and interactions among a number of enterprises and other organizations. Due to long-term cooperation of enterprises the organization form becomes a kind of network organization form beyond market and enterprises [22, 12], while this innovation form also becomes kind of innovation form beyond the dominants of large enterprises and small businesses. Especially with the condition of geographic agglomeration, many large, medium and small enterprises and other organizations of the same or relevant industries can form industrial cluster and conduct innovation activities. Hence the innovation vitality of independent individual SMEs will not be lost and the innovation resources of large enterprises are gained. Cluster innovation becomes a currently notable way to create regional innovation capability and the national innovation capability [19, 21, 4]. Industrial cluster supports innovation and value creation in the enterprises; on the other hand the companies also exploit the opportunities offered in the cluster [23]. Payne \& Leena (2005) defined the clusters innovation - many enterprises and other organizations on the base of division of responsibilities and spaces agglomeration cooperate mutually through the way of cluster and carry out long-term innovation activities [20].

The most important feature of industrial cluster is that it can generate innovative advantages. The innovative advantages of industrial cluster can be summarized as the followings. The first is collective learning. The learning activity of industrial cluster is different from the general Organizational Learning since the collective learning is achieved with the cooperation and coordination among all kinds of organizations and it can improve the ability of enterprises to decode information and absorb technology $[2,14]$. The second is knowledge spillover. The social exchanges by face-to-face among enterprises are increased because the enterprises are closed with each other in the space. The information technology and management methods related to the production and business will be rapidly spilled, shared, replicated and improved through formal and informal patterns, therefore new knowledge is created [25, 3]. The third is trust mechanism. It is easy for the enterprises in a cluster to form common norms and values. The enterprises that implement opportunism will be punished by all the enterprises in the cluster $[12,22]$. Trust is the foundation of business cooperation [1], which decreases the tendency to opportunism, reduces transaction costs and increases the likelihood of successful cluster innovation. The forth is inter-dependence and interaction. The industrial cluster is established based on the labor division and specialization so that the enterprise resources within a cluster are highly complementary and interdependent with highly frequent mutual exchanges and they have a close relationship of cooperation and innovation [13].

In terms of resource cities' transformation and development, many researchers focus on the research of government's financial assistance, preferential policies and the selecting of alternative industries. For example, Hennings and Kunzmann (1990) took Dortmund in Ruhr area of Germany as an example to carefully study the role of all levels in the government and institutions in the transformation [11]; Neil (1992) compared countries' support policies during the closure and transformation of mining factories in resource cities. Long et al. (2013) applied the theory of comparative advantages to discuss the selecting of alternative industries for Chinese resource cities. Although Grabher $(1991,2014)$ recognized that the cooperation between large and small enterprises is a new model in the transformation of resource cities, there are few scholars study the new strategy of cluster innovation in resource cities.

\section{Methodology}

This paper applies the methodology of case study and selects the typical cases not only from China but also from Britain and Germany. To select these cases, two criteria are applied. First, the identified cases are typical resource cities including the typology of unexhausted resource cities and exhausted resource cities. Second, the cases are good practices of the strategy of cluster innovation. Some cities are successful on transformation; some are making progress on implementing the strategy and building the industrial clusters. According to the two criteria, two categories of cases are selected. The first category of cases is cities in Britain and Germany that are successful on the application of strategy of cluster innovation. The Wales area of England and Ruhr area of Germany are selected as typical international cases, and mainly through the collection and analysis of literature and second-hand data. The second category is cities in China that are implementing the strategy of cluster innovation. One unexhausted resource cities-Baotou, and three exhausted resource cities-Benxi, Fuxin, and Liaoyuan, are selected as Chinese cases to make field research.

This research conducted semi-structured, in-depth qualitative interviews with selected 14 representatives of local government and enterprises, most of whom are engaged in economic transformation and strategic planning of these organizations. The interviews include 9 face to face interviews and 5 telephone interviews with an average duration of 35 minutes. This firsthand data collection was also complemented with a review of secondary material, such as the local statistics, reports, white papers and the organizations' websites. The comprehensive 
analysis of these fieldwork data provides the advices on the value, orientation and routes of cluster innovation Strategy for Chinese and other resource cities.

\section{International Experiences in Cluster Innovation of Resource Cities}

There are some resource cities in the countries which implemented industrialization earlier, such as Britain, Germany. These cities have developed into the recession or mature stage and have gradually achieved the economic transformation with the application of cluster innovation strategy that is valuable experience of the cities.

Cardiff, Swansea and other cities in Wales of UK once developed coal and steel as dominant industries. In 1700s and 1800s, Cardiff Bay was the one of the largest coal export port in the world. Since 1950s, these cities have gradually declined with the reasons of exhaustion of resources and rise of costs. Cluster innovation is an important strategy for Cardiff to revive, and Welsh Development Agency of Welsh government and other cities' relevant government agencies played an important role in implementation of this strategy. Since 1990, Cardiff and other cities promoted the economic transformation and the optimization of industrial structure vigorously [18]. The direction of transformation mainly focused on two industries, automobile \& aircraft manufacturing and electronic information industry, emphasizing on cultivating clusters in these two industries. Cardiff and other cities regarded the way of attracting foreign companies as the leverage to initiate industrial cluster. They attracted many investments of manufacturing companies from America and Japan by providing preferential policies on land and tax, also improved the ecological and urban environments. So these cities have been the area that attracts the most foreign investment in Britain. In the late of 1990s, Cardiff and other cities began to change the policy focus from the investment on "physical environment" to "service environment", such as technology transfer, skills training and business services and so on. Meanwhile they paid more attention to strengthen the embeddedness [10] of foreign enterprises in the local places. In "Regional Technology Development Plan" developed by Wales, they regarded the services of government departments as a bridge between local enterprises and foreign ones, and accelerated the spillover of knowledge and technology from foreign enterprises as an important development goal. Thereby Welsh Development Agency launched a "Source Wales" composed of the suppliers from local manufacturing in Wales, which is similar with the Suppliers Club in Japan, to increase the exchange and cooperation between local entrepreneurs and foreign ones. Welsh Development Agency also encouraged local enterprises to set up joint venture with foreign enterprises. Technology Club, Excellent Technology Center, "Skill Support Plan" and other organizations and activities providing technology and services were widely established in Wales [17]. Nowadays Cardiff and other cities have been leading the aviation, optical electronics, software and many other high-tech areas in the world as well as an attractive tourist resort after nearly 20 years of innovation and development.

Ruhr in Germany that flourished on the base of coal mining industry has been known as the "engine of German industry" for a long time. But Dortmund, Duisburg, Essen and other cities in this area declined together with the traditional coal, steel and machinery manufacturing industry since $1960 \mathrm{~s}$. From the middle of 1980 s, economic transformation, regional innovation and technology development are carried out on a large scale in Dortmund and other cities. The federal government had provided subsidies to the traditional industries trying to renew the economy at an early stage of transformation, but this measure did not bring about significant effects. Therefore, since the middle of $1990 \mathrm{~s}$, the federal government gradually reduced the subsidies to the coal, steel, shipbuilding and other sectors, only to finance the environmental protection, utilization of disused plants and other projects, meanwhile increased the subsidies to support the development of emerging industries, services industries and SMEs. The focus of policies were no longer on the construction of infrastructure, providing financial support to enterprises and so on, but on the creation and strengthening of the networks for the cooperation among enterprises, associations, research institutions, universities and government. In the process of developing new industries, Ruhr area learned from the experiences of Baden-Wurttemberg which is a new industrial center in Germany rapidly developing on the base of industrial cluster and actively implementing the strategy of cluster innovation. In Ruhr, almost every city had its own specific positioning of industrial clusters, and there was an initial link between cities. Table 1 lists the industrial clusters that were formed in Ruhr. Besides the promotion of the development of industrial cluster, the government of North Rhine-Westphalia where Ruhr area is located established the Ruhr Project Inc. in 2000 that aimed at promoting the technological innovation in cities. There were many trade organizations and entrepreneurs clubs in each city of Ruhr, many of which are public-private partnerships. They made the enterprises not only to be a cluster, but also an interactive network by strengthening communication and cooperation among enterprises and government agencies in order to promote innovation [15].

Along with Cardiff, Dortmund and other cities, Birmingham in the center of Britain, Glasgow in the North of Britain, Metz and Nancy in Lorraine area of France, Styria of Austria and other resource cities also promoted their regional innovation through the development of clusters innovation. 
Table 1. Industrial Clusters in Ruhr.

\begin{tabular}{lll}
\hline Centralized industries & Areas on the first level of cluster & Areas on the second lever of cluster \\
\hline Medicine & Essen & Cologne, Dusseldorf, Munster, Bochum \\
Medical devices & Bochum & Paderborn, Dusseldorf \\
IT, Media industry & Dortmund, Cologne & Dusseldorf, Bonn \\
Biology & Cologne, Dortmund & Decentralized \\
Chemical industry & Dormagen & Dortmund, Una, Cologne, Bonn \\
Logistics & Duisburg & Gelsenkirchen, Oberhausen \\
Energy & Dusseldorf, Essen & Decentralized \\
Tourism & Sauerland & \\
\hline
\end{tabular}

Source: Küpper, U. \& S. Röllinghoff (2005)

\section{Value of Cluster Innovation Strategy for Chinese Resource Cities}

There are more than 70 resource cities in China which are facing the problem of resource exhaustion and economic declination, such as Fuxin, Daqing, Fushun, and Liaoyuan. Therefore many problems are engendered in these cities, such as the closure and bankruptcy of enterprises, conspicuous problems of employment, residents' difficult lives, slow growth of economics as well as severe subsidence and environmental pollution. The majority of resource cities in China are part of the old industrial bases where the enterprises in resources mining, metallurgy, machinery manufacturing and other industries are centralized. However they are not industrial clusters. These kinds of industrial conglomerations are named as "Regional Production Complex" proposed by researchers of former Soviet Union. The differences between regional production complex and industrial cluster in resource cities are also the shortcomings existing in the industrial organizations of Chinese resource cities mainly as the followings. Firstly, resource cities are formed basically by national investment under the planned economic system mainly with state-owned economy. Secondly, in terms of organizational structure, one or a few large state-owned enterprises hold the leading role and the number of SMEs is small with low vitality. Thirdly, the industrial chain is short and lack of labor division and cooperation between enterprises limited to the logistics supplying relations of natural resources. Fourthly, the majority of state-owned resource enterprises are the national or provincial enterprises with the features of self-sufficiency and closed, ie. there are few exchanging activities between them and local cities and societies.

Therefore the direct causes of current recession in resource cities are the resources exhaustion and operation costs rise, while the rooted reason is: the planned economic system and traditional forms of industrial organizations do not provide a good breeding ground for innovation, which results in the low innovation capability of resource cities. In the analysis of Ruhr area, Grabher $(1993,1997)$ thought that Ruhr declined because the coal and steel production complex produced three kinds of lock-in effects including functional lock-in, cognitive lock-in and political lock-in [6, 7]. Chinese resource cities also have the three kinds of lock-in effects.
Since the beginning of new century, many resource cities in China have initiated the exploration of economic transformation. The main policy direction implemented is that the government provided huge financial support to the resource enterprises for technology improvement and gave subsidies to close and bankrupt resource enterprises. However these policies did not fundamentally endow resource cities with innovation capability. The strategy of cluster innovation exceeds the resource cities' partial and short-term policies, integrates the cities' innovation policies, industrial structure policies and industrial location policies, breaks the path dependence and lock-in effects, creates cities' benign innovation environment and innovation network through the improvement of industrial organizations and industrial location and ultimately accelerates cities' economic transformation and revival.

\section{Orientation and Routes of Cluster Innovation Strategy in Resource Cities}

Currently some of resource cities in China have spontaneously formed a number of industrial clusters or prototypes of cluster. Some local governments have also gradually realized the importance of cluster innovation and started planning the development of cluster innovation in local industries. For example, Baotou City, known as "the capital of lanthanon" in the world, has initially formed a internationally influential industrial cluster of lanthanon material and products of its application relying on Northern lanthanon Hi-Tech Co. Ltd., Baotou lanthanon Hi-Tech Industrial Development Zone and 13 scientific research institutes. For the cities like Baotou whose resources are not exhausted, an industrial cluster of continuous industries can be developed relying on the resources, but for some resource-exhausted cities, the target is to develop an industrial cluster of alternative industries. For example, the agate handicraft and manufacturing in Fuxin City has formed the cluster on Town of Shijiazi occupying 50\% market share in China. Especially this cluster has 30,000 employees absorbing a large number of laid-off workers from Fuxin Mining Group. Liaoyuan City where the coal mines are exhausted has also formed the biggest sock production area in the north of China. Benxi City, the exhausted iron mining city, take use of the renewable resources of local Chinese herb and bring together 
around 30 traditional Chinese medicine pharmaceutical companies to initially form a traditional Chinese medicine industrial cluster. See Table 2 for details. In general, the current development of cluster innovation in Chinese resource cities is only in its infancy with relatively weak innovation capability and the shortcomings mainly as the followings. The size of cluster is small and the market competitiveness is not high without strong leading enterprises; industrial chain is short and the division of labor and cooperation is not on a high level; there are a lot of low value-added products and the development of high-tech innovation cluster lags far behind; local governments do not make relevant industrial policies consciously on the orientation of cluster innovation. Thus, the strategy of cluster innovation deserves to have the attention from governments and enterprises of resource cities in the progress of economic transformation.

Table 2. Main industrial clusters formed in resource cities.

\begin{tabular}{|c|c|c|c|c|c|}
\hline Name of cluster & City and resource & Industry & $\begin{array}{l}\text { Number of } \\
\text { enterprises }\end{array}$ & $\begin{array}{l}\text { Annual output } \\
\text { value (billion \$) }\end{array}$ & $\begin{array}{l}\text { Employees } \\
\text { (thousand) }\end{array}$ \\
\hline Baotou lanthanon cluster & Baotou, Neimenggu (lanthanon) & mining & 75 & 1.21 & 15 \\
\hline Benxi traditional Chinese medicine cluster & Benxi, Liaoning (iron ore) & Pharmacy & 138 & 0.42 & 15 \\
\hline Liaoyuan sock manufacturing cluster & Liaoyuan, Jilin (coal) & Textile & 600 & 0.58 & 18 \\
\hline Fuxin agate handicraft and manufacturing cluster & Fuxin, Liaoning (coal) & Handcraft & 5000 & 0.21 & 60 \\
\hline
\end{tabular}

Note: The above figures are from the statistics of each city at the end of 2013.

Resource cities should emphasize the cluster innovation as the model of economic transformation and economic growth; meanwhile regard the development of industrial cluster and promotion of cluster innovation as the critical factors in making industrial policies. Furthermore, resource cities should push the old industrial bases which are previously centralized on the core of natural resources or capital to transform into modern industrial clusters on the core of regional innovation capability and overall competence of industry. The orientation of cluster innovation strategy in resource cities includes the following items. First, in terms of industrial structure, develop continuous industries and alternative industries through the way of industrial clusters to diversify the industrial structure of resource cities. Second, in terms of industrial organization, promote the development of SMEs and improve the level of specialization and cooperation among enterprises to enhance the cooperative R\&D and production as well as the social network. Third, in terms of industrial competitive edge, the cities should excavate regional endowment of resources and advantages of industrial foundation, encourage entrepreneurship and innovation, and create industrial competence on the core of innovation capability with comparative advantage. Fourth, in terms of industrial location, the cities should locate enterprises in industrial parks, office buildings, trading and displaying places as ways to promote a geographic agglomeration in the related industries. Fifth, in terms of industrial policy, the cities should avoid the restriction of administrative divisions between regions in cities, integrate the past industrial policies of regions or departments and implement the industrial policies system which is oriented to promote the cluster innovation. In short, the strategy of cluster innovation in resource cities aims at breaking the inherent lock-in effects of resource cities for a comprehensive and long-term improvement of regional innovation capability. The orientation and primary routes of breakthroughs to the lock-in effect are shown in Table 3. How resource cities implement the strategy of cluster innovation is a valuable topic to be further studied. Chinese and other resource cities should learn lessons from the experiences of foreign resource cities, such as Cardiff and Dortmund and take the following ways to promote cluster innovation.

Table 3. Orientation and Routes for Cluster Innovation to Break Lock-in Effects in Resource Cities.

\begin{tabular}{|c|c|c|c|}
\hline & Reasons of lock-in & $\begin{array}{l}\text { Orientation of } \\
\text { breakthroughs }\end{array}$ & Routes of breakthroughs \\
\hline $\begin{array}{l}\text { Functional } \\
\text { lock-in }\end{array}$ & $\begin{array}{l}\text { Single industrial } \\
\text { structure and strong } \\
\text { asset specificity }\end{array}$ & $\begin{array}{l}\text { Develop alternative industries } \\
\text { with industrial cluster }\end{array}$ & $\begin{array}{l}\text { - Develop a cluster of continuous industries, and extend the industrial chain } \\
\text { - Recognize the buds of cluster, and plan a cluster of alternative industries } \\
\text { - Encourage cooperative R\&D, production, etc. } \\
\text { - Attract investment from overseas, and promote the cooperation between foreign } \\
\text { enterprises and local ones } \\
\text { - Set up technology centers, and accelerate the spread of knowledge and technology }\end{array}$ \\
\hline $\begin{array}{l}\text { Cognitive } \\
\text { lock-in }\end{array}$ & $\begin{array}{l}\text { Conservative and } \\
\text { pessimistic values }\end{array}$ & $\begin{array}{l}\text { Encourage innovation and } \\
\text { entrepreneurship; build } \\
\text { learning regions }\end{array}$ & $\begin{array}{l}\text { - Create an atmosphere of public opinion advocating innovation } \\
\text { - Provide financing and technical support for innovation and entrepreneurship } \\
\text { - Enhance the training of laid-off workers and other people } \\
\text { - Governments strengthen the function of "network" and intermediary }\end{array}$ \\
\hline $\begin{array}{l}\text { Political } \\
\text { lock -in }\end{array}$ & $\begin{array}{l}\text { Draggle government } \\
\text { system and } \\
\text { management } \\
\text { organization }\end{array}$ & $\begin{array}{l}\text { Implement industrial policies } \\
\text { orienting to cluster innovation }\end{array}$ & $\begin{array}{l}\text { - Establish or improve the industry associations, entrepreneurs clubs, and } \\
\text { intermediary organizations } \\
\text { - Provide preferential policies and rewards to clusters and innovation } \\
\text { - Overall promote and publicize the image of local industrial cluster } \\
\text { - Accelerate the reform of SOEs and marketization of mining rights }\end{array}$ \\
\hline
\end{tabular}


First, focus on fostering regional networks of cooperation and innovation. Local governments should play their role in networking and serving as a bridge between suppliers and demanders in technologies and productions; promote the development and improvement of intermediary organizations; adopt the model of public-private partnership to promote the society to consciously form intermediary organizations, such as trading associations, entrepreneurs clubs and communication centers; build social networks and the weak ties [9] through launching salons, associations, conferences and other social activities to create an environment of integrity and trust and improve the accumulation of social capital in the cities. Meanwhile strengthening the embeddedness of foreign enterprises in the cluster is as important as the attraction of foreign investment; furthermore the support to cooperation between foreign enterprises and local ones might be accelerated.

Second, enhance the collective learning mechanism, and establish learning regions. If resource cities want to change the trend of recession, they need to enhance the cooperation and interaction between enterprises through the development of industrial clusters, completely play the roles of universities, research institutions, training institutions, trading associations and relevant government departments in promoting the learning and dissemination of knowledge, and create atmosphere of interactive learning and win-win, thereby enhance the ability of regional collective learning.

Third, select the development of industrial cluster from three types in line with local conditions. For the cities where resources are not exhausted, they can select to develop clusters of metallurgy and deep processing as lanthanon cluster of Baotou, which are the development of the continuous industries. For some resource exhausted cities, they are advised to focus on the development of the alternative industries to initiate several clusters of machinery manufacturing, textile and other traditional industries. For some resource cities that are desirable to develop high-tech industrial clusters, the city's industrial foundation, other natural resource endowments, human capital conditions, geographic conditions as well as the demands of market and competitive environment need to be taken into account, then make decision about the positioning and strategy after a comprehensive consideration of the advantages and disadvantages.

Fourth, accelerate the interaction between industrial parks and industrial clusters. Resource cities need to use the model of industrial clusters to improve the industrial parks since industrial park is the main carrier of industrial cluster. In the process of building industrial park, the cities should give priority to the existing clusters or the areas that are possible to form industrial clusters, specify the industrial positioning, and build specialized and professional industrial parks in order to create every industrial park into an innovative industrial cluster. On the other hand, the cities should promote to establish industrial parks within the existed and spontaneously formed clusters or their bud areas to remedy the shortage of industrial cluster in construction of hardware infrastructure, attraction of foreign investment, planning of geographical layout and regional image.

\section{Acknowledgements}

The study is supported by the Supported Program of Excellent Talents in Universities of Liao Ning Province (WR2013012) and China Natural Science Fund (71272052).

\section{References}

[1] Blois, K. J. (1999) Trust in Business to Business Relationships: An Evaluation of Its Status, Journal of Management Studies, 36 (2): 197-215.

[2] Capello, R. (1999) Spatial Transfer of Knowledge in High Techonology Milieux: Learning Versus Collective Learning Processes. Regional Studies, 33 (4): 353-384.

[3] Cooke P. (2002) Regional Innovation Systems: General Findings and Some New Evidence form Biotechnology Clusters, Journal of Technology Transfer, 27: 133-145.

[4] Delgado, M., Porter, M. E. and Stern, S. (2016) Defining Clusters of Related Industries, Journal of Economic Geography, 16 (1): 1-38.

[5] Grabher, G. (1991) Rebuilding Cathedrals in the Desert: New Patterns of Cooperation between Large and Small Firms in the Coal, Iron, and Steel Complex of the German Ruhr Area. In Bergman, E. M, etal. (eds): Regions Reconsidered: Networks, Innovation, and Local Development, New York: Mansell.

[6] Grabher, G. (1993) The Weakness of Strong Ties: The Lock-in of Regional Development in the Ruhr Area. In Grabher, G. (Eds). The Embedded Firm: on the Socioeconomics of Industrial Networks. London: Routledge.

[7] Grabher, G. \& Stark, D. (1997) Organizing Diversity: Evolutionary Theory, Network Analysis and Post-socialism. Regional Studies, 31 (5): 533- 544.

[8] Grabher, G. \& Ibert, O. (2014) Distance as asset? Knowledge collaboration in hybrid virtual communities, Journal of Economic Geography, 14 (1): 97-123.

[9] Granovetter, M. (1973) the Strength of Weak Ties. American Journal of Sociology, 78 (6): 1360-1380.

[10] Granovetter, M. (1985) Economic action and social structure: the problem of embeddedness. American Journal of Sociology, 91 (3): 481-510.

[11] Hennings, G. and Kunzmann, K. R. (1990) Priority to Local Economic Development: Industrial Restructuring and Local Development Responses in the Ruhr Area-the Case of Dortmund. In Stöhr, W. B. (eds): Global Challenge and Local Response, London and New York: Mansell.

[12] Jones, C., Hesterly, S. and Borgatti, P. S. (1997) a General Theory of Network Governance: Exchange Conditions and Social Mechanisms, Academy of Management Review, 22 (4): 911-945.

[13] Keeble, D and Wilkinson, F. (2000) High Technology Clusters, Networking and Collective Learning in Europe, Ashgate Publishing Ltd. 
[14] Kim, L. (2001) The dynamics of Technological Learning in Industrialization, International Social Science Journal, 53 (2): 297 308.

[15] Küpper, U. \& S. Röllinghoff. (2005) Cluster Management: Demands on Cities and Regional Networks, German Urban Study, 44 (1), https://www.difu.de/node/6029

[16] Long, R., Chen, H., Li, H., and Wang F. (2013) Selecting Alternative Industries for Chinese Resource Cities Based on Intra- and Inter-regional Comparative Advantages In: Energy Policy, 57: 82-88.

[17] Morgan, K. (1997) the Learning Regions: Institutions, Innovation and Regional Renewal, Regional Studies, 31 (5): 491-503.

[18] Neil, C., Tykkyläinen, M. and Bradbury, J. (1992) Coping with Closure: An International Comparison of Mine Town Experiences, London and New York: Routledge.

[19] OECD. (1999) Boosting Innovation: the Cluster Approac, OECD, Pairs.

[20] Payne, D. \& Leena, S. (2005) Construction Cluster Innovation,
Publication: International Journal of Strategic Property Management, 9 (2): 53-54.

[21] Porter, M. E. (2002) Clusters Innovation: Regional Foundations of U.S. Competitiveness, Report of Council on Competitiveness, Washington.

[22] Powell W. W. (1990) Neither Market nor Hierarchy: Network Forms of Organization, Research in Organizational Behavior, 12: $295-336$.

[23] Rubach, S. Johansen, F. R. (2014) Andersson, G. Missing Actions in Cluster Innovation. International Journal of Advanced Corporate Learning, 7 (1): 17-23.

[24] State Council of China, (2013) Planning for Sustainable Development of Resource Cities (in Chinese), $12^{\text {th }}$ of Nov.

[25] Tsoukas, H., (1996) the Firm as a Distributed Knowledge System: a Constructivist Approach, Strategic Management Journal, 17: 11-25.

[26] Yu, L., Yu, Z. and Jiang, C., Research on Industrial Transformation of Resource exhausted SOEs (In Chinese), Beijing: Chinese Social Science Press, 2008. 